\title{
Amelin: A 4.1-Related Spectrin-Binding Protein Found in Neuronal Cell Bodies and Dendrites
}

\author{
Keith E. Krebs, ${ }^{1}$ lan S. Zagon, ${ }^{2}$ and Steven R. Goodman' \\ The Cell and Molecular Biology Center, Departments of ${ }^{1}$ Physiology and ${ }^{2}$ Anatomy, The Milton S. Hershey Medical \\ Center, The Pennsylvania State University, Hershey, Pennsylvania 17033
}

\begin{abstract}
An immunoreactive, structural, and functional analog of erythrocyte protein 4.1 is present in neuronal cell bodies and dendrites. Other investigators have described the isolation of a 4.1 analog in brain with structural characteristics suggesting that its identity was synapsin I, a neuronal phosphoprotein localized in the presynaptic terminal in assoclation with small synaptic vesicles. In this report we demonstrate that the cell body/dendritic form of brain protein 4.1, which we have named amelin, is distinct from that of synapsin I on the basis of subcellular localization, migration in 2-dimensional gel electrophoresis, and structural criteria. We also demonstrate that amelin, like synapsin 1, can bind brain spectrin on nitrocellulose paper. Neither amelin nor synapsin I binds calmodulin, as determined by a blot binding assay. We hypothesize that there exists in brain a family of 4.1-related proteins with distinct subcellular localization and function.
\end{abstract}

An analog of erythrocyte protein 4.1 has been identified in the cell bodies and dendrites of neurons, as well as in the cell bodies of certain glial cells (Goodman et al., 1984a). On the basis of immunoblotting of pig brain proteins separated by SDS-PAGE (in a continuous buffer system; Fairbanks et al., 1971) with an antibody against pig red blood cell (rbc) protein 4.1 , the brain protein 4.1 was assigned an apparent molecular weight of 87 $\mathrm{kDa}$. Tryptic peptide mapping of this brain protein 4.1 analog versus that of rbc protein 4.1 indicated partial structural homology (Goodman et al., 1984a). These findings were significant because rbc protein 4.1 serves to stimulate the binding of rbc spectrin to actin, as well as to link the cytoskeleton and the membrane bilayer (sec revicw by Goodman et al., 1984b). Therefore it was possible that brain protein 4.1 might serve a similar function in the neuron.

Subsequent work by others (Baines and Bennett, 1985) indicated that a brain protein that was identified as an analog of rbc protein 4.1 appeared to be identical to the neuronal phosphoprotein designated synapsin I (DeCamilli et al., 1983). This brain protein 4.1 analog and synapsin I both consisted of a doublet of polypeptides of $\sim 75$ and $73 \mathrm{kDa}$ on SDS-PAGE in

\footnotetext{
Received Nov. 26, 1986; revised June 3, 1987; accepted June 5, 1987.

This study was supported by a fellowship from the $\Lambda H \Lambda$, South Central PA Chapter (K.E.K.), and by NIH Grants NS-19357, HL-26059 (S.R.G.) and NS21246 (I.S.Z. and S.R.G.). S.R.G. is an Established Investigator of the American Heart Association. We thank J. Dimeler and J. Schwartz for help on the manuscript and D. Sitler for photographic assistance. The authors also gratefully acknowledge Dr. M. L. Billingsley's assistance on the calmodulin overlay experiments.

Correspondence should be addressed to Dr. K. E. Krebs at the above address. Copyright (C) 1987 Society for Neuroscience $0270-6474 / 87 / 123907-08 \$ 02.00 / 0$
}

discontinuous buffer systems (I aemmli, 1970), but migrated with an apparent molecular weight of $\sim 87 \mathrm{kDa}$ in continuous buffer systems (Baines and Bennett, 1985; for a review, see Goodman and Zagon, 1986). The finding that a brain protein 4.1 analog was identical to synapsin I has justifiably received a great deal of attention, as synapsin $I$ is thought to play an important role in synaptic transmission (see Nestler and Greengard, 1983 for a review). However, this finding raised the question of whether synapsin I was equivalent to the brain protein 4.1 analog originally described (Goodman et al., 1984a) or, alternatively, whether there were 2 distinct brain protein 4.1 analogs. The fact that synapsin I has been reported to be localized exclusively on the cytoplasmic surface of synaptic vesicles in the presynaptic terminals of neurons (DeCamilli et al., 1983) has suggested that the latter possibility might be correct. In this report we demonstrate that the brain protein 4.1 analog described by Goodman and colleagues (1984a), which we have named amelin (from the Greek amelew, to overlook), is structurally and immunologically distinct from synapsin I, and we have confirmed the fact that these 2 brain protein 4.1 analogs have different locations within neurons.

These studies have been presented in preliminary form (Goodman et al., 1986).

\section{Materials and Methods \\ Protein purification}

Mouse brain total protein. Mice (C57 BL/6J) were anesthetized with ether and perfused through the heart with PBS ( $5 \mathrm{~mm} \mathrm{NaPO}_{4}, \mathrm{pH} 7.4$, $155 \mathrm{~mm} \mathrm{NaCl}$ ) until the perfusate was clear. The brains were immediately removed and frozen in liquid nitrogen. Five brains $(2 \mathrm{gm})$ were homogenized at $2000 \mathrm{rpm}$ with a Teflon homogenizer in $50 \mathrm{ml}$ of chloroform/methanol $(2: 1, \mathrm{vol} / \mathrm{vol})$ containing $0.25 \mathrm{~mm}$ phenylmethylsulfonyl fluoride, and the filtrate was prepared by the procedure of Chou et al. (1976). The protein precipitate was redissolved in $10 \mathrm{ml}$ of nonequilibrium $\mathrm{pH}$ gradient gel electrophoresis (NEPHGE) sample buffer $(9 \mathrm{M}$ urea, $2 \%$ Triton $\mathrm{X}-100,5 \% \beta$-mercaptoethanol and $0.8 \%$ ampholine), as described by O'Farrell et al. (1977), and frozen in $500 \mu \mathrm{l}$ aliquots at $-70^{\circ} \mathrm{C}$ for later use.

Mouse brain spectrin. Forty mice were perfused as described above. Brain spectrin was isolated as described (Goodman et al., 1983). Previous studies have demonstrated that spectrin isolated by this protocol yields a mixture of brain spectrin(240/235) and brain spectrin(240/ 235E) (Riederer et al., 1986). SDS-PAGE revealed an essentially pure preparation of spectrin. The mouse brain spectrin was iodinated by the method of Bolton and Hunter (1973) as described, and was dialyzed against 2 changes of assay buffer [ $80 \mathrm{mM} \mathrm{KCl}, 20 \mathrm{mM} \mathrm{NaCl}, 5 \mathrm{~mm}$ $\mathrm{NaPO}_{4}, \mathrm{pH} 7.4,1 \mathrm{~mm}$ EGTA, $0.25 \mathrm{~mm}$ dithiothreitol (DTT)]. The ${ }^{125} \mathrm{I}$-brain spectrin had a specific activity of $26 \mu \mathrm{Ci} / \mathrm{mg}$.

Calmodulin. Calmodulin was purified from bovine brain using mellitin-Sepharose affinity chromatography (Kincaid and Coulson, 1985). Calmodulin was biotinylated in the presence of $\mathrm{Ca}^{2+}$ by reaction using 
biotinylepsilon-amino-caproic acid $N$-hydroxysuccinamide ester as described (Billingsley et al., 1985).

Antibody production. Pig erythrocyte protein 4.1 was purified to homogeneity by the published procedure (Tyler et al., 1980) for use as an immunogen. Pure bovine dephospho-synapsin I was produced by our published procedure (Krebs et al., 1986a). Antibodies were produced as described (Krebs et al., 1986a). The pig erythrocyte 4.1 antiserum cross-reacted exclusively with erythrocyte 4.1 at 1:300 dilution (Goodman et al., 1984a), and the synapsin I antisera cross-reacted exclusively with the synapsin I doublet at a 1:1000 dilution (Krebs et al., 1986a).

Immunohistochemistry. A mouse was perfused, the cerebellum immediately frozen in Freon-12, and cryostat sections $(10 \mu \mathrm{m})$ prepared for indirect immunofluorescent studies using rhodamine-conjugated goat anti-rabbit IgG (Cappel Laboratories) as previously described (Goodman et al., 1984a). Cryostat sections were incubated with pig rbc 4.1 antisera or bovine synapsin I antisera at 1:50 dilution in PBS containing $2 \%$ normal goat serum (NGS). Controls were performed using preimmune rabbit serum adjusted to give an IgG concentration identical to that of the rbc 4.1 antiserum. The sections were mounted and photographed with an Olympus fluorescence microscope.

Electrophoresis and protein transfer. The total brain protein filtrate $(150 \mu \mathrm{l})$ was loaded onto $1.5 \times 10.5 \mathrm{~cm}$ NEPHGE $(\mathrm{pH} 8-10.5$ or $6-$ $10.5)$ tube gels, as described by O'Farrell et al. (1977). The proteins were electrophoresed at $400 \mathrm{~V}$ constant voltage for $4 \mathrm{hr}$, and the gels were electrophoresed in the second dimension in a 7\% polyacrylamide gel using the Laemmli discontinuous buffer system (Laemmli, 1970). The gels were stained with Coomassie blue, or electrophoretically transferred as described (Towbin et al., 1979) to nitrocellulose (Millipore, $0.45 \mu \mathrm{m}$ ). Blots were either stained with amido black, reacted with antisera, or overlayed with ${ }^{125} I$-spectrin or biotinylated calmodulin.

Immunoblotting. Duplicate electrophoretic transfers of the NEPHGE pH 8-10.5 gel were incubated with pig rbc 4.1 antisera (1:300 dilution) or bovine synapsin I antisera (1:1000 dilution) in TBSB [10 mm Tris, $\mathrm{pH} 7.4,155 \mathrm{~mm} \mathrm{NaCl}, 5 \%$ non-fat dried milk (Carnation), $0.05 \%$ Tween20] for $12 \mathrm{hr}$. The transfers were incubated for $3 \mathrm{hr}$ at $25^{\circ} \mathrm{C}$ with TBSB containing ${ }^{125} \mathrm{I}$-protein $\mathrm{A}$ ( $\mathrm{sp}$ act, $\left.80 \mathrm{cpm} / \mu \mathrm{l}\right)$. The transfers were autoradiographed (Kodak X-Omat XAR-5 film) with a Dupont Cronex Lightning Plus intensifying screen for $2 \mathrm{~d}$ (rbc 4.1 antisera) or $12 \mathrm{hr}$ (synapsin I antisera) at $-20^{\circ} \mathrm{C}$.

125I-Brain spectrin overlay. Duplicate electrophoretic transfers of the NEPHGE pH 6-10.5 gel were incubated with ${ }^{125}$ I-mouse brain spectrin $(10 \mathrm{~nm})$ or ${ }^{125} \mathrm{I}$-heat-denatured $\left(90^{\circ} \mathrm{C}\right.$ for $\left.15 \mathrm{~min}\right)$ brain spectrin for $3 \mathrm{hr}$ at $25^{\circ} \mathrm{C}$, with constant shaking in assay buffer $(80 \mathrm{~mm} \mathrm{KCl}, 20 \mathrm{~mm} \mathrm{NaCl}$, $5 \mathrm{~mm} \mathrm{NaPO}$, pH 7.4, $1 \mathrm{~mm}$ EGTA, $0.25 \mathrm{~mm}$ DTT, 5\% non-fat dried milk, $0.05 \%$ Tween-20). The transfers were autoradiographed with an intensifying screen for $66 \mathrm{hr}$ at $-20^{\circ} \mathrm{C}$.

Biotinylated calmodulin overlay. Nitrocellulose electroblots obtained from NEPHGE 2-dimensional gels were incubated in TBSB for $12 \mathrm{hr}$ at $4^{\circ} \mathrm{C}$, washed 3 times in TBSB containing $1 \mathrm{mM} \mathrm{Ca}^{2+}$, and incubated with biotinylated calmodulin ( $25 \mu \mathrm{g}$ in $10 \mathrm{ml} \mathrm{TBSB} / \mathrm{I} \mathrm{mM} \mathrm{Ca}{ }^{2+}$ ) for 30 $\min$ at $25^{\circ} \mathrm{C}$. Blots were then washed 3 times in TBSB $/ 1 \mathrm{mM} \mathrm{Ca}^{2+}$, and bound biotinylated calmodulin was detected using avidin-alkaline phosphatase complexes (BioMeda Labs) dissolved in TBSB $/ 1 \mathrm{mM} \mathrm{Ca}{ }^{2+}$. After a $30 \mathrm{~min}$ incubation, blots were washed 3 times in TBSB/1 mM $\mathrm{Ca}^{2+}$, which was followed by chromogenic development using nitroblue tetrazolium chloride $(200 \mu \mathrm{l}$ at $50 \mathrm{mg} / \mathrm{ml}$ in $50 \%$ dimethylformamide; Amresco) and 5-bromo-4-chloro-3-indoyl phosphate $p$-toluidine salt $(100 \mu 1$ at $50 \mathrm{mg} / \mathrm{ml}$ in $100 \%$ dimethylformamide); both dissolved in $30 \mathrm{ml}$ of $0.1 \mathrm{M}$ Tris- $\mathrm{HCl}, \mathrm{pH} 9.5,100 \mathrm{mM} \mathrm{NaCl}, 50 \mathrm{~mm}$ $\mathrm{MgCl}_{2}$. One lane of the second-dimension NEPHGE gel was loaded with a mixture of bovine brain calcineurin, caldesmon, and spectrin as positive controls for biotinylated calmodulin binding; the proteins were prepared from bovine brain using calmodulin affinity chromatography (Billingsley et al., 1985).

Iodopeptide maps. The Coomassie blue-stained bands corresponding to mouse amelin and mouse synapsin Ib from 2-dimensional gel electrophoresis, and the Coomassie blue-stained band corresponding to mouse erythrocyte $4.1 \mathrm{~b}$ from mouse erythrocyte ghosts, electrophoresed in a $7 \%$ polyacrylamide gel with discontinuous buffer system, were excised and iodinated in the gel slices with ${ }^{125}$ I-NaI (Amersham) as described (Elder et al., 1977). The iodinated proteins were digested with $\alpha$-chymotrypsin and the digests were electrophoresed and chromatographed as described (Goodman et al., 1982).

Protein determination. Protein concentrations were determined by a modification of the method of Bradford (1976), using bovine serum albumin as a standard.

\section{Results}

Immunohistochemical localization of amelin and synapsin I Immunohistochemical analysis was performed on $10 \mu \mathrm{m}$ cryostat sections of mouse cerebellum stained with a rabbit antibody against pig rbc 4.1 (Goodman et al., 1984a) or bovine synapsin I, followed by rhodamine-conjugated goat anti-rabbit IgG. The pig rbc 4.1 antibody is the identical antibody used and characterized in the original description of brain protein 4.1 (Goodman et al., 1984a), and the synapsin I antibody stains the synapsin Ia and Ib doublet exclusively (Krebs et al., 1986a). The comparative, low-magnification overview of the cerebellum stained with anti-rbc 4.1 (Fig. $1 A$ ) or anti-synapsin I (Fig. $1 D$ ) clearly indicated that these antibodies were detecting different antigens. The rbc 4.1 antibody moderately stained the internal granule layer, but only weakly stained the molecular and medullary layers (Fig. 1A). A higher-magnification view of the internal granule layer (Fig. $1 B$ ) indicated that the thin rim of cell body cytoplasm of each granule cell neuron was being stained by the rbc 4.1 antibody. Purkinje cell bodies were also stained (Fig. 1A), as were their dendrites (not shown). Axons were not stained by the rbc 4.1 antibody. Alternatively, the synapsin I antibody intensely stained the molecular layer, moderately stained the internal granule layer, and weakly stained the medullary layer (Fig. $1 D$ ). The bright staining of the molecular layer (Fig. 1D), and the bright staining of glomeruli between granule cells (Fig. $1 E$ ), is consistent with the localization of synapsin I in presynaptic terminals, as described by Greengard and colleagues (DeCamilli et al., 1983). We have not observed staining of neuronal cell bodies, dendrites, or axons with this synapsin I antibody. Sections incubated with preimmune serum demonstrated negligible staining of the internal granule layer (Fig. $1 C$ ) or the molecular layer of the cerebellum (Fig. $1 F$ ). Therefore, while the rbc 4.1 antibody was recognizing an antigen present in neuronal cell bodies and dendrites (as well as certain glial cells; Goodman et al., 1984a), the synapsin I antibody specifically stained synaptic terminals.

\section{Separation of amelin and synapsin I in 2-dimensional $\mathrm{NEPHGE}_{\mathrm{NaDodSO}}-\mathrm{PAGE}$ gels}

The antibody against rbc protein 4.1 that was used in this study has previously been demonstrated to specifically cross-react with a single polypeptide with an apparent molecular weight of 87 $\mathrm{kDa}$ when total brain homogenate protein was separated by 1-dimensional SDS-PAGE in a continuous buffer system (Goodman et al., 1984a). As we have previously demonstrated that this rbc 4.1 antibody cross-reacts with a single brain protein of $87 \mathrm{kDa} M_{\mathrm{r}}$ in this continuous buffer system (Fairbanks et al., 1971 ), and that synapsin I also migrates as a single broad band of $\sim 87 \mathrm{kDa}$ in this gel system (Goodman and Zagon, 1986), we wanted to determine whether synapsin I was the protein being detected. We therefore chose to use the higher-resolution technique of 2-dimensional gel electrophoresis, consisting of NEPHGE in the first dimension, followed by second-dimension SDS-PAGE in a discontinuous buffer system. As shown in Figure 2, when mouse brain extract was subjected to NEPHGE/ SDS-PAGE, amelin (as recognized by anti-rbc protein 4.1) migrated as a basic protein (ran to a $\mathrm{pH}$ of 8.5) with an apparent molecular weight of $\sim 93 \mathrm{kDa}$ (Fig. $2, A, C$ ). In contrast, synapsin I (as recognized by anti-synapsin I) was a more basic protein than amelin (synapsin I migrated to a $\mathrm{pH}$ of 10.3), which split into a doublet of 76 and $70 \mathrm{kDa}$ (Fig. 2, $A, B$ ). This 2-dimen- 
sional gel system demonstrates that amelin (the protein recognized by this rbc 4.1 antibody) differs from synapsin I in both isoelectric point and apparent molecular weight.

\section{Amelin is a spectrin-binding protein}

It had previously been shown that synapsin I is capable of binding ${ }^{125} \mathrm{I}$-brain spectrin by a blot binding assay (Baines and Bennett, 1985). Using a similar blot binding assay, both amelin and synapsin I, separated by the NEPHGE 2-dimensional gel system, bound ${ }^{125} \mathrm{I}$-brain spectrin (Fig. $3 \mathrm{C}$ ), which was isolated by a protocol (Goodman et al., 1983) that yields a mixture of brain spectrin(240/235) and brain spectrin(240/235E) (Riederer et al., 1986). In addition to amelin and synapsin I, 3 proteins of 178 , 159 , and $124 \mathrm{kDa}$ apparent $M_{\mathrm{r}}$ bound ${ }^{125} \mathrm{I}$-spectrin. Lower-molecular-weight spots of 40-20 kDa, which correspond to known synapsin I breakdown products (as determined by cross-reactivity with antisera against synapsin I), also bound ${ }^{125} \mathrm{I}$-brain spectrin. The possibility that the binding of ${ }^{125} \mathrm{I}$-brain spectrin to proteins adsorbed to nitrocellulose paper may represent nonspecific binding to basic proteins appears unlikely for several reasons. (1) Of the $\sim 71$ protein spots observed on the amido black-stained blot of the brain homogenate protein separated by the NEPHGE 2-dimensional gel system (Fig. $3 \mathrm{~A}$ ), only 11 are capable of binding spectrin (Fig. $3 C$ ); 7 of the 11 spectrinbinding proteins have already been identified as amelin, synapsin Ia, synapsin Ib, and synapsin I proteolytic fragments. (2) The proteins on the blot that most efficiently bind brain spectrin are a doublet of neutral proteins (which ran to a $\mathrm{pH}$ of 7.5) that can barely be detected on the amido black-stained blot (Fig. $3 A$ ), but are clearly stained on the ${ }^{125} \mathrm{I}$-brain spectrin blot (arrowhead in Fig. $3 C$ ). (3) Although synapsin Ia and Ib are sequence-related, extremely basic proteins with nearly identical isoelectric points, synapsin Ia binds ${ }^{125}$ I-brain spectrin strongly, while the binding to synapsin $\mathrm{Ib}$ is very weak (Fig. $3 C$ ). This result cannot be reconciled with the conclusion that binding of ${ }^{125}$ I-brain spectrin to proteins attached to nitrocellulose paper is nonspecific. (4) The proteins in the blot in Figure $3 C$ did not bind the heat-denatured ${ }^{125} \mathrm{I}$-brain spectrin (Fig. $3 D$ ). Heat denaturation of spectrin has typically been used as a specificity control for spectrin interactions. Under the conditions used $\left(90^{\circ} \mathrm{C} / 15 \mathrm{~min}\right)$, only $11 \%$ of the brain spectrin becomes precipitable (sediments at 40,000 $\times \mathrm{g}, 30 \mathrm{~min}$ ). Therefore, we believe that heat denaturation is a better control than competition with high concentrations of brain spectrin $(1 \mathrm{mg} / \mathrm{ml})$, where the majority of spectrin becomes precipitable.

The ${ }^{125} \mathrm{I}$-spectrin-blotting experiment indicates that amelin attached to nitrocellulose paper has the capacity to bind spectrin. When amelin is purified to homogeneity, binding studies in solution will be required to confirm this result, while establishing the affinity and stoichiometry of this interaction.

Neither amelin nor synapsin I bound biotinylated calmodulin; however, the $61 \mathrm{kDa}$ subunit of calcineurin, caldesmon (135 $\mathrm{kDa}$ ), and the $240 \mathrm{kDa}$ subunit of brain spectrin did exhibit biotinylated calmodulin binding (Fig. $3 B$ ).

\section{Amelin and synapsin I are structurally distinct}

To determine the extent of structural relatedness between amelin and synapsin I, we carried out a comparison of the 2-dimensional chymotryptic iodopeptide maps of amelin, synapsin I, and erythrocyte protein 4.1 (Fig. 4). There was little homology ( $\sim 17 \%$ spot overlap) between amelin (Fig. $4 B$ ) and synapsin I (Fig. $4 C$ ). The peptide maps of amelin (Fig. $4 B$ ) and rbc protein
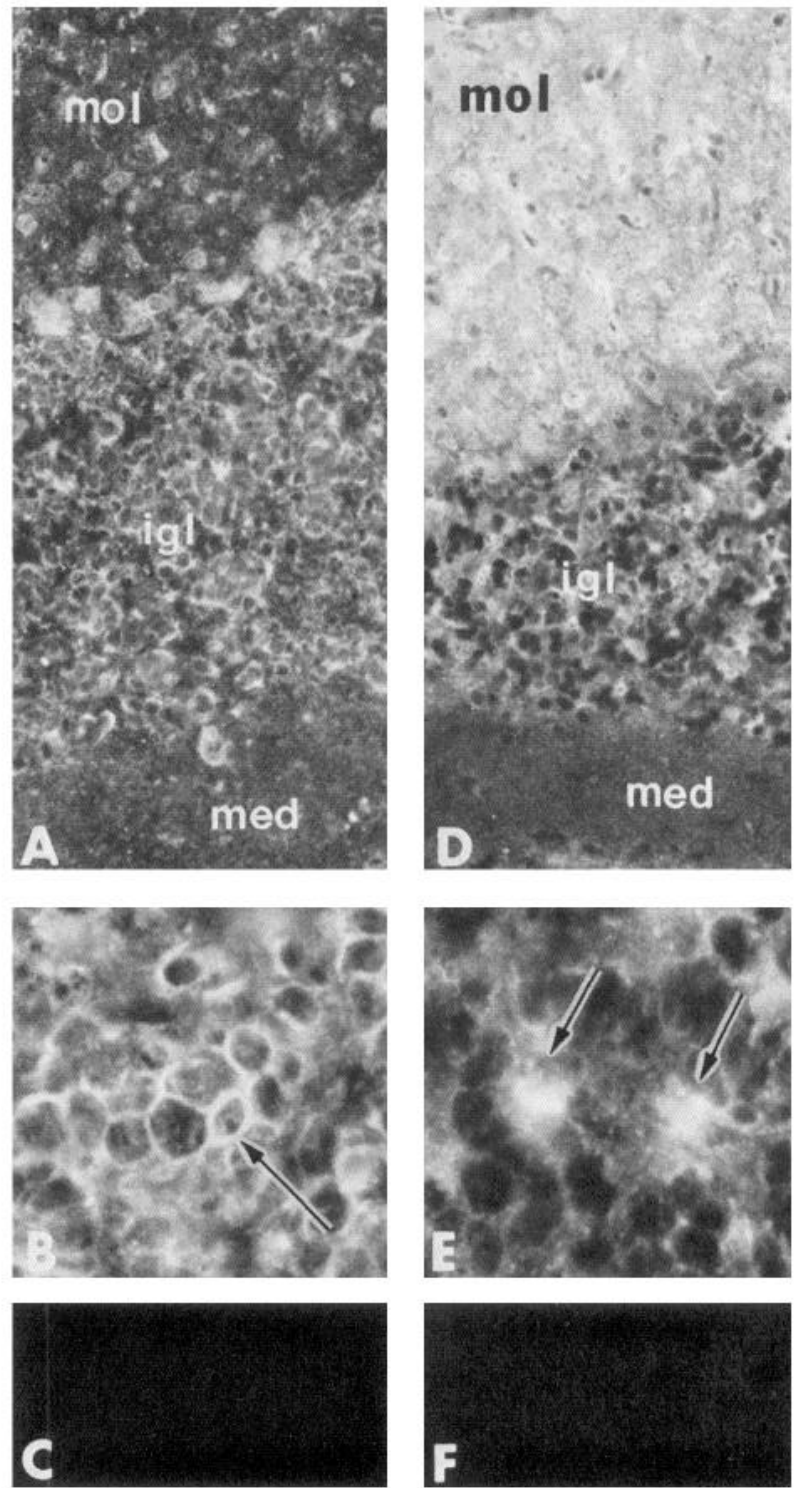

Figure 1. Subcellular localization of amelin and synapsin I in mouse cerebellum. An adult mouse (C57 BL/6J male) was perfused as described in Materials and Methods, the cerebellum immediately frozen in Freon12 , and cryostat sections $(10 \mu \mathrm{m})$ prepared for indirect immunofluorescent studies using rhodamine-conjugated goat anti-rabbit IgG. $A$, Low-magnification $(240 \times)$ photograph of the cerebellum stained with antibody to erythrocyte 4.1 . Bright fluorescence of the internal granule layer $(i g l)$ and low fluorescence of the molecular $(\mathrm{mol})$ and medullary $(\mathrm{med})$ layers are shown. The most striking feature $(B)$ was the intense fluorescence of the cortical cytoplasm (arrow) of the granule cells, more clearly seen under higher magnification $(850 \times)$. $C$, Control stained with preimmune serum demonstrated no staining of igl $(850 \times)$. $D$, Lowmagnification $(240 \times)$ photograph of cerebellum stained with antibody against synapsin $I$. The intense fluorescence of the molecular layer is clearly demonstrated. In addition, patchy fluorescence of the igl, and low fluorescence of the medullary layer were observed. Higher magnification $(850 \times)$ of the igl $(E)$ demonstrated the staining of the glomeruli contacting granule cells (arrows). Control stained with preimmune serum demonstrated no staining of $\mathrm{mol}(850 \times)(F)$.

4.1 (Fig. $4 A$ ) demonstrate partial homology ( $\sim 50 \%$ spot overlap), while a comparison of the map of synapsin I with that of rbc protein 4.1 reveals fewer common spots $(\sim 33 \%$ spot overlap). Therefore, amelin is structurally distinct from synapsin I and appears to be more structurally related to rbc protein 4.1 


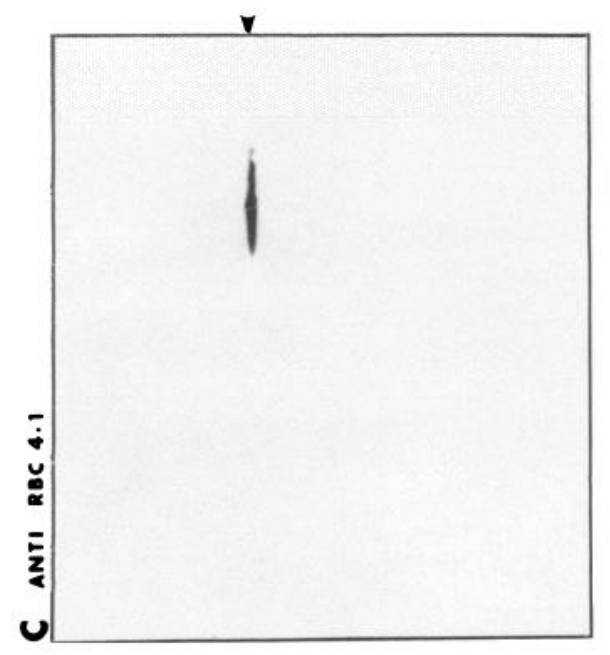

เั่์

농

吾变

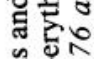

㞼.

密 으

政

등.

떵 를

和

要

कै

四 寻

.

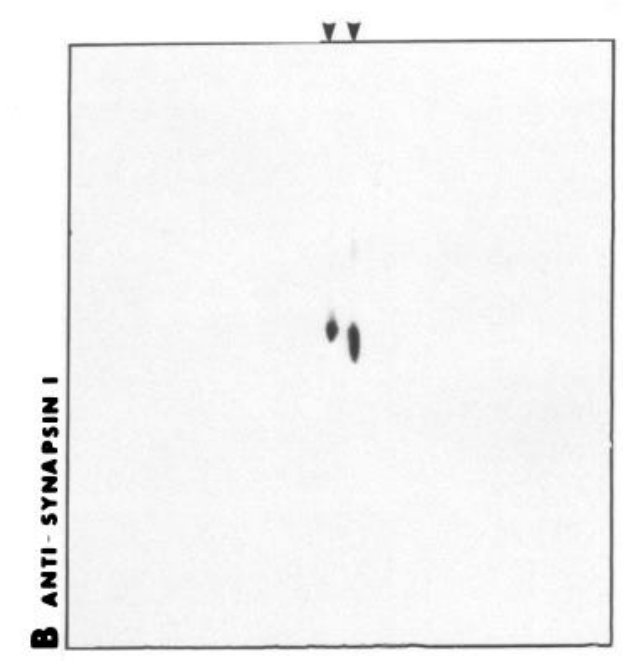

乙彭

สํํำ

象次

हैं क्ष

ปิ

형

릉

엉

일

해욤

․ㅡㄹ

둥

옹

ㅁ⿺ㄹ

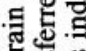

s.

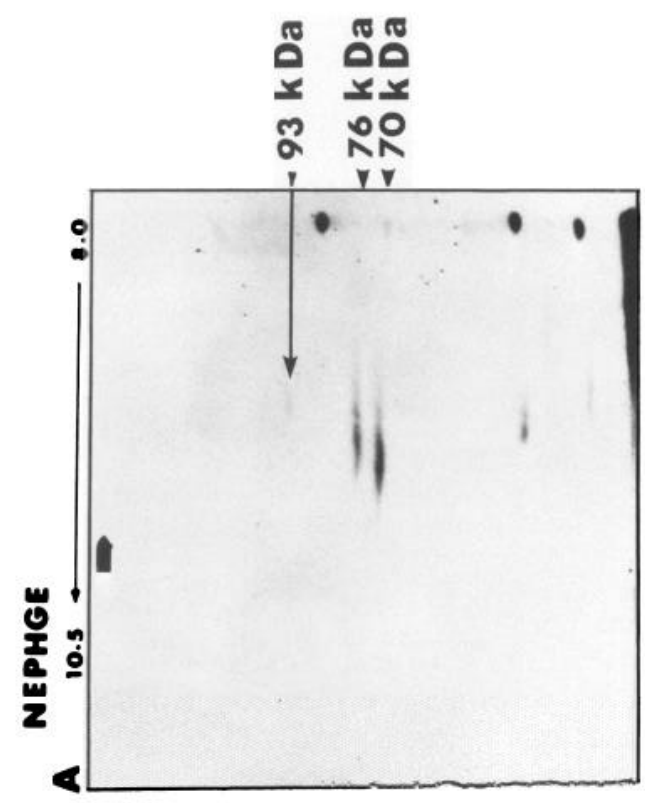

政

음을

的或

등

동중

宅.

응

옹

글

สี สํ

ङ.

현흥

政

论

등

is

3 웡

3 s

نํ.

ڤั 
A

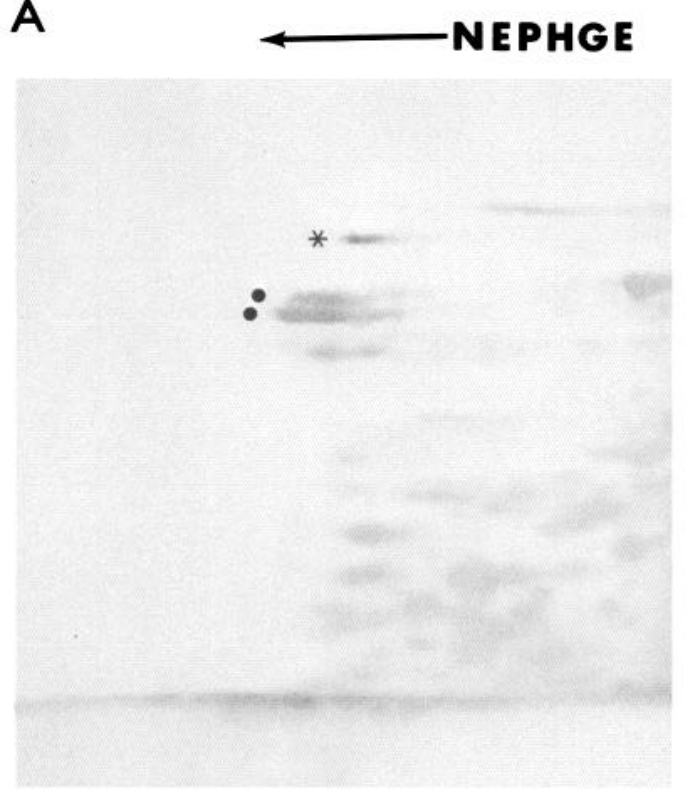

B

\section{0 kD>}

135 kD

$61 \mathrm{kD}-$
C

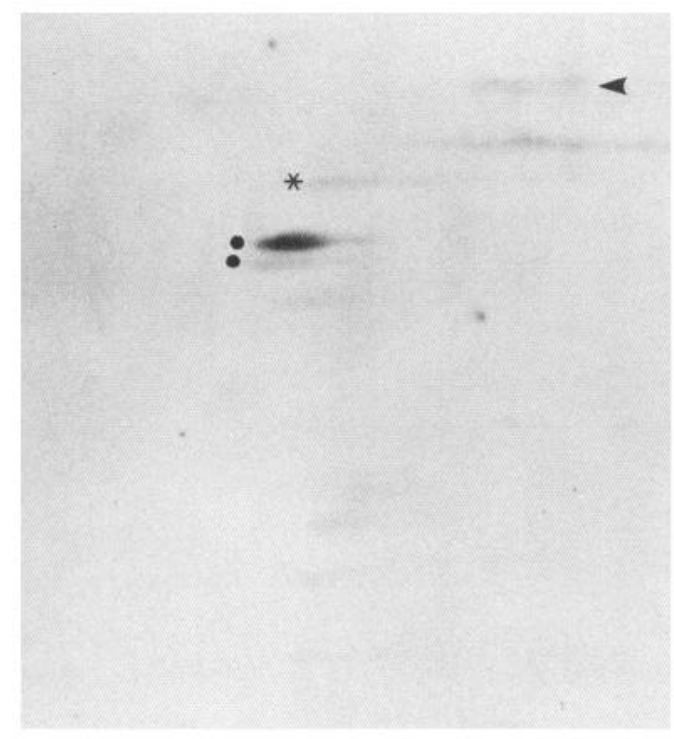

D

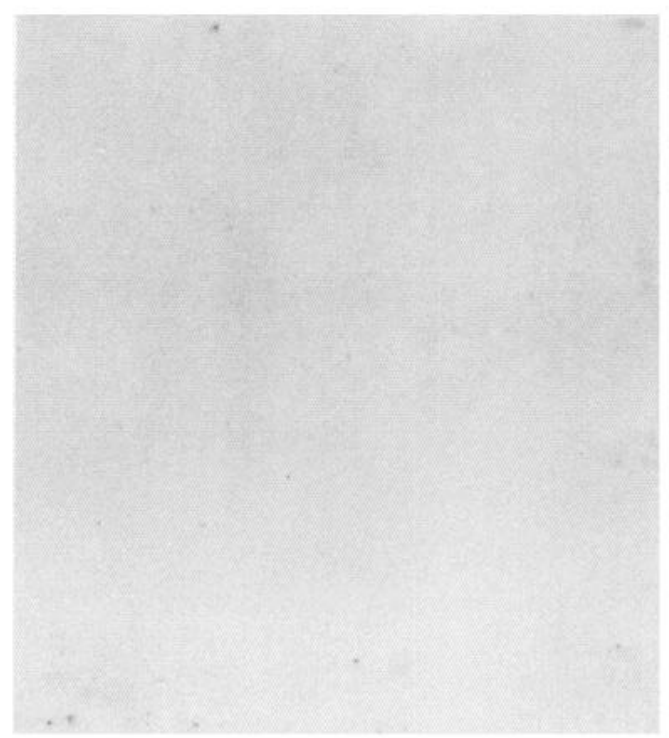

Figure 3. Biotinylated calmodulin and ${ }^{125} \mathrm{I}$-brain spectrin overlay of 2-dimensional gel transfers. Total brain proteins were electrophoresed in a pH 6-10.5 NEPHGE gel, followed by electrophoresis in a 7\% SDS-polyacrylamide gel using the Laemmli buffer system in the second dimension. The proteins were transferred to nitrocellulose and reacted with amido black, biotinylated calmodulin, or ${ }^{125}$ I-brain spectrin. $A$, Amido black staining of proteins. *, Amelin, , synapsin I. B, Biotinylated calmodulin overlay visualized with alkaline phosphotase. The calmodulin-binding proteins brain spectrin $(240 \mathrm{kDa})$, calcineurin $(135 \mathrm{kDa})$, and caldesmon $(61 \mathrm{kDa})$ are indicated in the reference lane by arrows. $C$, ${ }^{125} \mathrm{I}-$-brain spectrin overlay. *, Amelin, ४, 178 and $159 \mathrm{kDa}$ doublet, $\bullet$, synapsin I. D, Heat-denatured ${ }^{125}$ I-brain spectrin control overlay.

than synapsin I. A more complete analysis of structural similarities between amelin, synapsin $\mathrm{I}$, and rbc protein 4.1 will require sequence analysis.

\section{Discussion}

In this study we have demonstrated that the brain protein 4.1 analog originally described by Goodman et al. (1984a), and now termed amelin, is distinct in structure and location from syn- apsin I. Amelin is a basic protein with a molecular weight of $\sim 93 \mathrm{kDa}$. The antibody against rbc protein 4.1 cross-reacts with this immunoreactive brain analog, which is localized to the cell body and dendrites of neurons and to the soma of certain glial cells. Amelin, like synapsin I, is capable of binding ${ }^{125}$ I-brain spectrin, while neither amelin nor synapsin I appears to be a calmodulin-binding protein. The partial structural homology between amelin and rbc protein 4.1 observed on peptide map- 


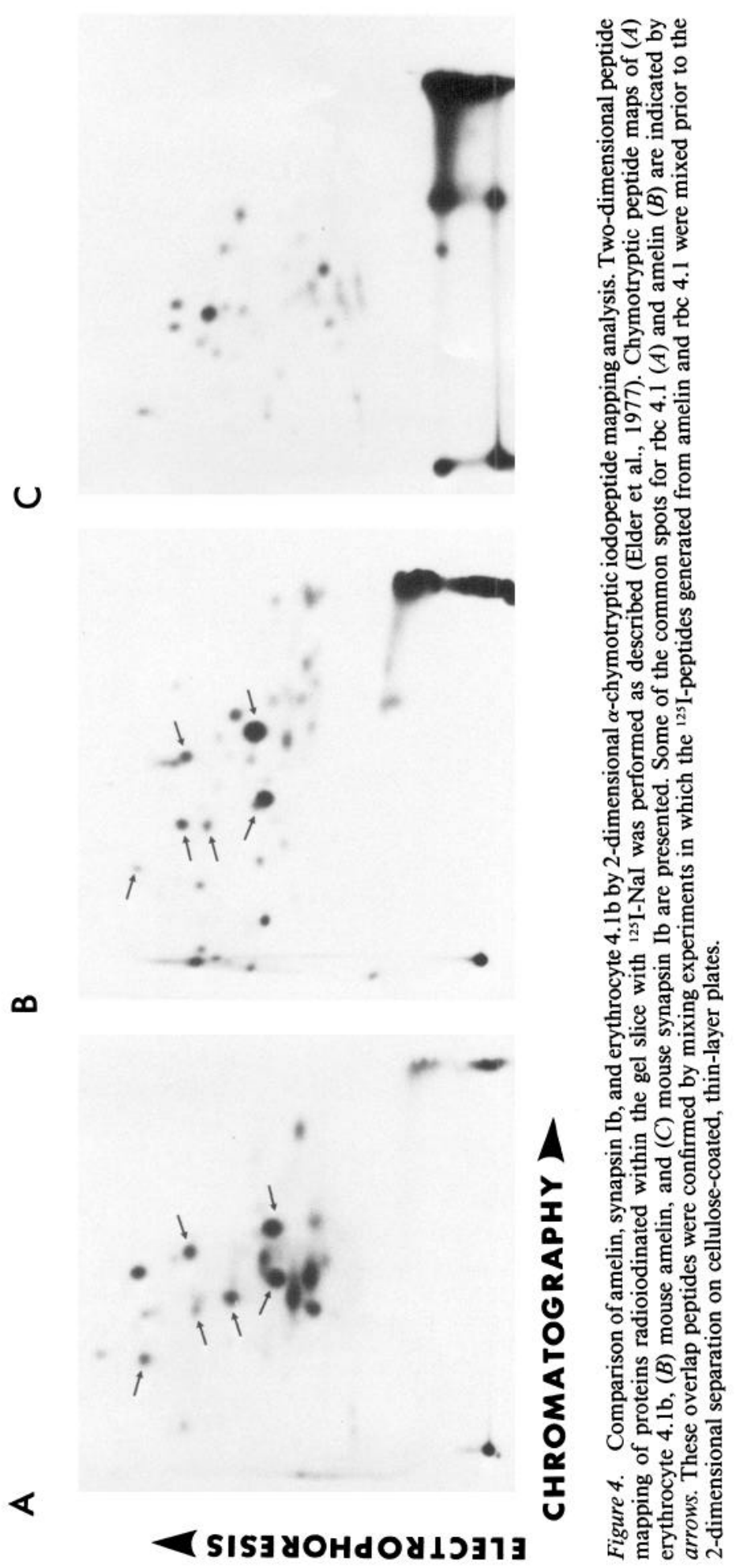


ping, their common epitopes, recognized by rbc 4.1 antibody, and the ability of amelin to bind brain spectrin in blot binding assays justifies amelin's inclusion as a 4.1-related protein. Indeed, amelin appears to be more structurally related to rbc protein 4.1 than does synapsin I. The isolation of amelin will be required to determine the stoichiometry and affinity of amelin binding to brain spectrin, and its ability to stimulate the brain spectrin-actin interaction.

Synapsin I is more basic than amelin, and is composed of sequence-related polypeptides of 76 and $70 \mathrm{kDa}$. We see only weak cross-reactivity between our rbc protein 4.1 antibody and synapsin I. In separate studies, we have demonstrated a difference of 3 orders of magnitude between the ability of this antibody to detect rbc protein 4.1 and its ability to detect synapsin I in competitive quantitative dot assays (Krebs et al., 1986c). We chose this antibody for these studies because it was the original antibody used to define brain protein 4.1 (Goodman et al., 1984a), and its very weak cross-reactivity with synapsin 1 allowed us to compare and contrast the immunohistochemical localization of amelin and synapsin I. Two other polyclonal antibodies against rbc 4.1 in our laboratory (one against human rbc 4.1 and another against pig rbc 4.1 ) cross-react with amelin, and only weakly, if at all, with synapsin I (K. E. Krebs and S. R. Goodman, unpublished observations). The extent of crossreactivity between rbc 4.1 antibody and synapsin I reported by others (Baines and Bennett, 1985) is difficult to assess, owing to the possibility of differences in antisera specificity, and to the fact that the exposure times of immunoautoradiographs were not presented. Synapsin I also demonstrates little obvious structural homology to rbc protein 4.1 , as analyzed by 2 -dimensional peptide mapping. Rat brain synapsin Ib and human erythrocyte protein 4.1 cDNA have recently been cloned and sequenced, and the lack of substantial sequence homology confirms our conclusions from peptide mapping (Conboy et al., 1986; McCaffery and DeGennaro, 1986). The amino acid sequences aligned from their $\mathrm{N}$-termini reveal just $5 \%$ identical amino acids and only 19\% homology if conservative substitutions of amino acids are made (Steiner et al., 1987). Therefore, one would predict from the sequences that polyclonal antibodies against rbc protein 4.1 would react weakly or not at all with synapsin 1, depending on whether any epitopes resided in the small regions of common sequence. Except for the antibody described by Baines and Bennett (1985), all other antibodies against rbc 4.1 have been reported to cross-react very weakly or not at all with synapsin I (Goodman and Zagon, 1986; Kanda et al., 1986; Krebs et al., 1987). Despite these differences, synapsin I has strong functional similarities to rbc protein 4.1.

Synapsin I binds to the $\alpha$ and $\beta$ subunits of brain spectrin immobilized on nitrocellulose paper in a manner similar to the binding of rbc protein 4.1 to rbc spectrin (Baines and Bennett, 1985). The spectrin binding in Figure $3 C$ indicates that synapsin Ia may bind brain spectrin with higher affinity than does synapsin $\mathrm{Ib}$, suggesting that the spectrin-binding site may be at an end of synapsin Ia. If this result can be confirmed by other approaches, it has important implications. Recently, McCaffery and DeGennaro (1986) reported that the sequence of rat brain synapsin $\mathrm{Ib}$ reveals no homology with a 67 amino acid peptide of human erythrocyte protein 4.1 suggested to be involved in promoting spectrin-actin interactions (Correas et al., 1986). On the basis of their sequence data, McCaffery and DeGennaro (1986) proposed that synapsin Ia differs from synapsin Ib only at its C-terminal end, the difference being $\sim 40$ additional amino acids. If synapsin Ia can bind brain spectrin, while synapsin Ib binds brain spectrin only weakly, it is possible that the binding site resides within these 40 amino acids at the C-terminal end of synapsin Ia. This would explain why a sequence related to the spectrin-binding domain of erythrocyte protein 4.1 was not found in the total sequence of synapsin Ib.

Recently, we demonstrated that dephospho-synapsin I binds to spectrin in solution with a $K_{\mathrm{d}}$ and stoichiometry that are nearly identical to those of the binding of rbc protein 4.1 to rbc spectrin (Tyler et al., 1980; Krebs et al., 1987). In addition, rotary shadowing and electron microscopy of the brain spectrinsynapsin I complex has indicated that synapsin I binds to the terminal ends of the brain spectrin tetramer, analogous to the binding of rbc 4.1 to the rbc spectrin tetramer (Krebs et al., 1985; Goodman and Zagon, 1986; Krebs et al., 1987). Finally, synapsin I can stimulate the binding of brain spectrin(240/235) to F-actin (Krebs et al., 1986a, b), a function that is identical to the essential function of rbc protein 4.1 (Goodman et al., 1984b). The close functional relationship between synapsin I and rbc protein 4.1 justifies identifying synapsin $I$ as a 4.1 related protein. Synapsin I has been localized to the presynaptic terminals of neurons (DeCamilli et al., 1983), and our study is in accord with that location. Recently, neuronal cell body dendritic, axonal, and presynaptic terminal staining of adult rat cerebellum has been observed using antibody against synapsin I (Goldenring et al., 1986). It is not clear whether this result represents staining of both amelin and synapsin I or, alternatively, a more widespread distribution of synapsin I throughout the neuron.

The findings in this study fit well with the recent discovery of 2 distinct spectrin isoforms in mammalian brain (Riederer et al., 1986). Brain spectrin(240/235) is not recognized by rbc spectrin antibodies and is localized to neuronal axons and presynaptic terminals. Brain spectrin $(240 / 235 \mathrm{E})$ is antigenically related to rbc spectrin and is found in neuronal cell bodies and dendrites, as well as in glial soma. It is possible that synapsin I stimulates the binding of brain $\operatorname{spectrin}(240 / 235)$ to F-actin in the presynaptic terminal, holding synaptic vesicles in place until the appropriate signal. A recent immunoelectron-microscopic study has clearly demonstrated the association of brain spec$\operatorname{trin}(240 / 235)$ with synaptic vesicles in situ (Zagon et al., 1986). Amelin, on the other hand may stimulate the binding of brain spectrin(240/235E) to F-actin in the neuronal cell body and dendrites, as well as link brain $\operatorname{spectrin}(240 / 235 \mathrm{E})$ to the cytoplasmic surface of the plasma membrane and organelle membranes (Zagon et al., 1986). By analogy to the erythrocyte, such an association may be essential to the neuronal membrane's structural integrity.

\section{References}

Baines, A. J., and V. Bennett (1985) Synapsin is a spectrin binding protein immunologically related to erythrocyte protein 4.1 . Nature 315: 410-413.

Billingsley, M. L., K. R. Pennypacker, D. J. Brigati, C. G. Hoover, and K. L. Kincaid (1985) A rapid and sensitive method for detection and quantification of calcineurin and calmodulin binding proteins using biotinylated calmodulin. Proc. Natl. Acad. Sci. USA 82: 7585 7589 .

Bolton, A. E., and W. M. Hunter (1973) The labelling of proteins to high specific radioactivity by conjugation to a ${ }^{125}$ I-containing acylating agent. Biochem. J. 133: 529-539.

Bradford, M. M. (1976) A rapid and sensitive method for the quantitation of microgram quantities of protein utilizing the principle of protein-dye binding. Anal. Biochem. 72: 248-254. 
Chou, F. C. H., C. H. J. Chou, R. Shapira, and R. F. Kibler (1976) Basis of microheterogeneity of myelin basic proteins. J. Biol. Chem. 251: 2671-2679.

Conboy, J., Y. W. Kan, S. B. Shohet, and N. Mohandas (1986) Molecular cloning of protein 4.1 , a major structural element of the human erythrocyte membrane skeleton. Proc. Natl. Acad. Sci. USA 83:95129516.

Correas, I., T. L. Leto, D. W. Speicher, and V. T. Marchesi (1986) Identification of the functional site of erythrocyte protein 4.1 involved in spectrin-actin associations. J. Biol. Chem. 261: 3310-3315.

DeCamilli, P., R. Cameron, and P. Greengard (1983) Synapsin I (protein I), a nerve terminal-specific phosphoprotein I. Its general distribution in synapses of the central and peripheral nervous system demonstrated by immunoflorescence in frozen and plastic sections. J. Cell Biol. 96: 1337-1354.

Elder, J. H., R. A. Pickett, J. Hampton, and R. A. Lerner (19\%7) Radioiodination of proteins in single polyacrylamide gel slices. J. Biol. Chem. 252: 6510-6515.

Fairbanks, G., T. L. Steck, and D. F. H. Wallach (1971) Electrophoretic analysis of the major polypeptides of the human erythrocyte membrane: Biochemistry 10: 2606-2617.

Goldenring, J. R., R. S. Lasher, M. L. Vallap, T. Ueda, S. Naito, N. H. Sternberger, L. A. Sternberger, and R. J. DeLorenzo (1986) Association of synapsin I with neuronal cytoskeleton. Identification of cytoskeletal preparation in vitro and immunocytochemical localization in brain of synapsin I. J. Biol. Chem. 261: 8495-8504.

Goodman, S. R., and I. S. Zagon (1986) The neural cell spectrin skeleton: A review. Am. J. Physiol. 250 (Cell Physiol. 19): C347C360.

Goodman, S. R., J. Yu, C. F. Whitfield, E. Culp, and E. J. Posnak (1982) Erythrocyte membrane skeletal proteins $4.1 \mathrm{a}$ and $\mathrm{b}$ are sequence related phosphoproteins. J. Biol. Chem. 257: 4564-4569.

Goodman, S. R., I. S. Zagon, C. F. Whitfield, L. A. Casoria, P. J. McLaughlin, and T. Laskiewicz (1983) A spectrin-like protein from mouse brain membranes: Immunological and structural correlations with erythrocyte spectrin. Cell Motil. 3: 635-647.

Goodman, S. R., L. A. Casoria, D. B. Coleman, and I. S. Zagon (1984a) Identification and location of brain protein 4.1 . Science 224: 14331436.

Goodman, S. R., K. Shiffer, D. B. Coleman, and C. F. Whitfield (1984b) Erythrocyte membrane skeletal protein 4.1: A brief review. In The Red Cell: Sixth Ann Arbor Conference, Progress in Clinical and Biological Research, vol. 165, G. J. Brewer, ed., pp. 415-439, Liss, New York.

Goodman, S. R., I. S. Zagon, V. Bennett, G. Lynch, and M. Willard (1986) Symposium. Brain spectrin: Structure, location, and function. Soc. Neurosci. 12: 942.

Kanda, K., T. Tanaka, and K. Sobue (1986) Calspectrin (fodrin or nonerythroid spectrin)-actin interaction: A possible involvement of
4.1 related protein. Biochem. Biophys. Res. Commun. 140: 10511058.

Kincaid, R. L., and C. C. Coulson (1985) Rapid purification of Calmodulin and S- 100 protein by affinity chromatography with mellitin immobilized to Sepharose. Biochem. Biophys. Res. Commun. 133: 256-264.

Krebs, K. F., R. K. Sihag, R. Higbee, I. S. 7agon, and S. R. Gondman (1985) Synapsin I, a species of brain protein 4.1 , binds to the ends of brain spectrin tetramer. J. Cell Biol. 101: 287a.

Krebs, K. E., I. S. Zagon, and S. R. Goodman (1986a) A rapid purification of synapsin I: A neuron specific spectrin binding protein. Brain Res. Bull. 17: 237-241.

Krebs, K. E., I. S. Zagon, and S. R. Goodman (1986b) Synapsin I stimulates the spectrin $(240 / 235) / \mathrm{F}$-actin interaction in a phosphorylation dependent manner. J. Cell Biol. 103: 292a.

Krebs, K. E., A. C. Nairn, M. Bähler, W. Schiebler, I. S. Zagon, P. Greengard, and S. R. Goodman (1986c) The relationship of erythrocyte protein 4.1 to the neuron specific phosphoprotein synapsin $I$. J. Cell Biol. 103: 542a.

Krebs, K. E., S. M. Prouty, I. S. Zagon, and S. R. Goodman (1987) The structural and functional relationship of rbc protein 4.1 to synapsin I. Am. J. Physiol. (in press).

Laemmli, U. K. (1970) Cleavage of structural proteins during the assembly of the head of bacteriophage T4. Nature 227:680-685.

McCaffrey, C. A., and L. J. DeGennaro (1986) Determination analysis of the primary structure of the nerve terminal specific phosphoprotein synapsin I. EMBO J. 5: 3167-3173.

Nestler, E. J., and P. Greengard (1983) Protein phosphorylation in the brain. Nature $305: 583-588$.

O'Farrell, P. Z., H. M. Goodman, and P. H. O'Farrell (1977) High resolution two-dimensional electrophoresis of basic as well as acidic proteins. Cell 12: 1133-1142.

Riederer, B. M., I. S. Zagon, and S. R. Goodman (1986) Brain spectrin(240/235) and brain spectrin(240/235E): Two distinct spectrin subtypes with different locations within mammalian neural cells. J. Cell Biol. 102: 2088-2096.

Steiner, J. P., K. Gardner, A. Baines, and V. Bennett (1987) Synapsin I: A regulated synaptic vesicle organizing protein. Brain Res. Bull. 18: 777-785.

Towbin, H., T. Staehelin, and J. Gordon (1979) Electrophoretic transfer of proteins from polyacrylamide gels to nitrocellulose sheets: Procedure and some applications. Proc. Natl. Acad. Sci. USA 76: 43504354.

Tyler, J. M., B. N. Reinhardt, and D. Branton (1980) Associations of erythrocyte membrane proteins. Binding of purified bands 2.1 and 4.1 to spectrin. J. Biol. Chem. 255: 7034-7039.

Zagon, I. S., R. Higbee, B. M. Riederer, and S. R. Goodman (1986) Spectrin subtypes in mammalian brain: An immunoelectron-microscopic study. J. Neurosci. 6: 2977-2986. 